Оригинални научни рад

$349.412(439)$

doi:10.5937/zrpfns51-14099

Csilla Csák, Ph.D., Assistant Professor

University of Miskolc

Faculty of Law

dattila@yunord.net

\title{
THE REGULATION OF AGRICULTURAL LAND OWNERSHIP IN HUNGARY AFTER LAND MORATORIUM
}

\begin{abstract}
Arable land is one of the most valuable natural resources of the country, which shall comprise the nation's common heritage; the responsibility to protect and preserve them for future generations lies with the State and every individual - we can read it in the Section (1) of Article P) of the Fundamental Law of Hungary. The new Act on the transaction of land (Act CXXII of 2013 on Transactions in Agricultural and Forestry Land), which was adopted by the Parliament on 21 June 2013, serves the realization of these purposes, and regulates the essential and dominant elements of land acquisition after the moratorium on land. The regulation formulates such legal institutions, substantive and procedural rules, which are able to guarantee the interest of the country. In the framework of the study we will present and analyze the EU's expectations and principles, and on the other hand, the Hungarian solutions concerning to transaction of land.
\end{abstract}

Keywords: agricultural land, forest land, property rights, foreigners rights.

\section{HUNGARIAN REGULATION BY VIRTUE OF EC/EU CONTRACTS}

Hungary - before the accession to the EU-arranged the requirements for fulfilling the conditions of the accession and the derogation conditions including the question of land moratorium in the framework of EC/EK contracts. On the basis of the Act of Accession (Article 24) of 2003 Hungary could differ from EU law transitionally in the issue of arable land. According to the Act of Accession Hungary could have maintained in force for seven years from the date of its accession to the EU- the prohibitions contained in law adapted on the acquisition of arable land by natural persons who are non-residents or non nationals of Hungary 
and by legal persons. A national of any Member States or a legal person established in another Member State can not be treated less favourably in the respect of the acquisition of arable land than enjoyed on the date of sign of the Act of Accession. An exceptional rule was drafted of the derogation under which the nationals of another Member State who wishes to settle down in Hungary as a self-employed farmer and have been living in Hungary legally for at least 3 years and do agricultural activities, other rules and procedure can not be applied to them than to Hungarian citizens. Considering these European Union commitments the former Act of Agricultural Land (Act LV of 1994) was amended on the acquisition of ownership by foreigners and two categories were established: acquisition of ownership by a) a national of a Member State b) non-EU national. Nationals of a Member State could acquire land ownership in the same manner with the Hungarian citizens during the period of moratorium, whether they fulfilled specific conditions: they have lived in Hungary for 3 years and have done agricultural activities and wish to maintain agricultural activities in the future. Other foreigners -as a rule- could not acquire land ownership in Hungary.

The Act of Accession (Annex X) provided opportunity for the extension of transitional period. If there is sufficient evidence that, upon expiry of the transitional period (2011), there will be serious disturbances or a threat of serious disturbances on the agricultural land market of Hungary, the Committee, at the request of Hungary, shall decide upon the extension of the transitional period for up to a maximum of three years. On this basis Hungary initiated the extension of the seven years moratorium for up to three years in accordance with the authorisation in $2 / 2010$. (II. 18.) Parliamentary Decision. In support of the serious disturbances on the agricultural land market Hungary put forward the following arguments: a) Community agricultural support given for Hungary will reach the average of old Member State only from 2013; b) the average land prices in Hungary are far behind the land prices of the majority of Member States which threaten with serious disturbances on the post-2011 agricultural land market; c) land consolidation process started after the change of regime has not been finished yet. ${ }^{1}$

Hungary received three-year more moratorium until 30 April, 2014 as a result of a Commission Decision ${ }^{2}$ - on the basis of the Hungarian arguments- but this extension may not be extended further. The expiry of land moratorium means that from this date farmers of the Member States can also acquire the ownership of arable lands in Hungary under the rules applicable to Hungarian farmers. In the category of foreigners different regulation can not be maintained for nationals of a Member State. As for the membership of the EU from 1 May, 2014 (expiry of land moratorium)

\footnotetext{
${ }^{1}$ See Csák Csilla-Nagy Zoltán: Regulation of Obligation of Use Regarding the Agricultural Land in Hungary ZBORNIK RADOVA PRAVNI FAKULTET (NOVI SAD) 45.:(2) pp. 541-549. (2011) Collected papers. Novi Sad, Szerbia 2011

${ }^{2}$ Commission Decision, 2010/792/EU
} 
Hungary had to abolish the different Hungarian and European Union prohibitions and restrictions related to the acquisition of arable land by nationals of Member States. ${ }^{3}$

\section{LEGAL BACKGROUND OF THE ACQUISITION OF AGRICULTURAL LANDS}

\subsection{EU rules}

EU law does not contain direct regulation on land ownership of Member States, its regulation essentially falls within the competence of the Member States. However, EU law sets out principles and regulatory approaches in primary and secondary law and in the case-law of the European Court of Justice which shall be taken into consideration by the Member States. Despite the fact Member States are entitled to regulate the ownership independently, their regulation may not infringe the fundamental rights of the EU. Provisions of the Treaty on the Functioning of the European Union state the principle of non-discrimination (Article 18), right of establishment (Article 49), free movement of capital (Article 63) including investment in real estate. ${ }^{4}$ On the basis of the interpretation of case-law of the European Court of Justice (ECJ) national law can not distinguish between nationals of the EU based on their nationality. According to the principle of freedom of movement for persons and capital, the principle of national treatment shall be respected and restrictive provisions comply with EU law only if they pursue public interest and restrictive provisions can not be replaced by other provisons -less restrictive for the freedom of movement for capital. Legal public interests are e. g. maintaining of rural population, ensuring the life and cultivation of agricultural land by their owners, the CAP's objectives, etc. Restrictive national provisons based on established practice are e. g. transfer of the ownership of arable land under a prior administrative permission, the requirement of residence, prior declaration system, higher taxation on land sale shortly after acquisition, the requirement of longer minimum period for lease contract of agricultural land, etc. ${ }^{5}$

${ }^{3}$ Comprehensive analysis of regulation before the accession period can be found Csilla Csák - János Ede Szilágyi: Legislative tendencies of land ownership acquisition in Hungary, Agrarrecht Jahrbuch 2013, 2013, 215-233.

${ }^{4}$ 88/361/ EEC Council Directive, see also Commission Decision, 2010/792/EU, Hunagrian regulation had to take into account other requirements too such as human rights, e. g. right to property, see Anikó Raisz, Földtulajdoni és földhasználati kérdések az emberi jogi bíróságok gyakorlatában, in: Csilla Csák (ed.): Az európai földszabályozás aktuális kihívásai, Novotni Alapítvány, Miskolc, 2010, 241-253.; András Téglási, Az alapjogok hatása a magánjogi viszonyokban az Alkotmánybíróság gyakorlatában az Alaptörvény hatálybalépését követõ elsõ három évben, Jogtudományi Közlöny, 2015/3, 148-157.

${ }^{5}$ Financial law provisions and agrimonetary analisation related to land ownership issues can be found in studies of Zoltán Nagy: Nagy Zoltán: A termőfölddel kapcsolatos szabályozás 
According to the case-law of ECJ a land policy which promotes and maintains the establishment of small and medium sized holdings by equitable distribution of agricultural lands is essentially in accordance with the objective of increasing the farmers' quality of life of Common Agricultural Policy.

The legislation of Member States place great emphasis on the regulation of the possible acquisition within strict framework. However, margin of Member States' holding policy is uncertain in many points from EU law aspect. The uncertainty -inter alia- may derive from the fact that such a Member State policy, in accordance with the Common Agricultural Policy "supported" by the ECJ's practice, which aim is the equitable distribution of agricultural lands, the reduction of speculation pressure and the maintenance of rural population, essentially raises the incompatibility between the applied measures and economic fundamental freedoms. Analyzing the new practice of the European Court of Justice we can conclude that even if the preservation of local communities is a "public interest" recognized by EU law, however, the applied measures are not equivalent to the principle of proportionality. The intent of new Member States (and their farmers) is to establish a fair distribution, viable holdings becomes significantly difficult compare to the old Member States (and farmers resident in there) which results beside de jure equal treatment de facto different treatment and margin. ${ }^{6}$

Therefore, Hungary after the end of land moratorium (2014) provided the acquisition of the ownership of arable land by nationals of Member States according to the regulatory conditions applicable to Hungarian people without making any distinction between the acquisition by nationals and nationals of Member States. Furthermore, in the Hungarian regulation -taking advantage of the use of restrictive provisions- cogent substantive and procedural conditions of land acquisition are found which we will introduce in detailed follows below:

\subsection{The basis of national legislation}

The condition of holding structure and the development directions are fundamentally determined by substantive and procedural law regulating the ownership and use of conditions of agricultural lands (holdings) and by the priority of agricultural financing and rural development in connection with the customised-tool system of agricultural policy. The two areas are closely linked to each

pénzügyi jogi aspektusai, in: Csák Csilla (edit.): Az európai földszabályozás aktuális kihívásai, Miskolc, Novotni Alapítvány, 2010, 187-197.; Nagy Zoltán: A mezőgazdasági tevékenységet végzők adójogi szabályozása egyes jövedelemadóknál, Publicationes Universitatis Miskolcinensis Sectio Juridica et Politica, Miskolc University Press, Miskolc, Tomus XXIII/2 (ann. 2005), 333-349.

${ }^{6}$ László Fodor explained his position about the period of land moratorium: ,it is double standard used by the EU at the expense of Member States. The fake being of land moratorium, inter alia lies in the fact that the possibility of 7 years given for closing land prices is and was derogated by lower subsidy level (compared to former Member States). 
other but focus on partly different problem areas and focal points. The target areas of Common Agricultural Policy a) viable food production, b) sustainable management of environmental resources, c) balanced development of rural areas. The regulation determining the ownership and use of conditions and framework also aims to achieve these objectives. The direction of new legislation (from 2014) is to develop a viable holding structure and to maintain rural population. The following land policy objectives were defined in the Act on Transactions in Agricultural and Forestry Land:

- enhancement of villages with a view to maintaining populations level and to enhancing the income potential

- development of agricultural community and within it of family partnerships, local businesses

- diversification of dual structure

- creating the conditions of sustainable land use

- promoting the operation of newly developed farming structure

- viable and economically feasible land size

- eliminating the consequences of fragmented estate structure.

In Hungary two opposite processes can be observed in the structure of holdings: on one hand fragmentation (fragmented estate structure), on the other hand land concentration. Fragmentation is basically due to the fact that there is no specific inheritance regulation for agricultural holdings and land. ${ }^{7}$ Establishing the sui generis inheritance system and increasing the number of young farmers, who are local resident and do agricultural activities, may help to achieve the objectives. It is necessary to mention the acquiring party herein, the scope and way of acquisition.

Arable land is one of the most valuable natural resources which comprise the nation's common heritage; responsibility to protect and preserve them for the future generations lies with the State and every individual-as we can read in the first paragraph of Article P) of Fundamental Law. The new land transaction adopted by the Parliament on 21 June 2013 (Act CXXII of 2013 on Transactions in Agricultural and Forestry Land).

In addition, beside the new land transaction act - pursuant to paragraph 2, Article P of Fundamental Law- which is the first step in the regulation of social

${ }^{7}$ Several people argue for introducing the special regulation of agricultural land (and holdings) (e. g. Csák, Hornyák, Prugberger, Szilágyi); lásd Zsófia Hornyák, Földöröklési kérdések jogösszehasonlító elemzésben, in: Szabó Miklós (ed.): Miskolci Egyetem Doktoranduszok Fóruma: ÁJK szekciókiadványa, ME TNRT, Miskolc, 2016, 131-135.; Zsófia Hornyák - Tamás Prugberger, A föld öröklésének speciális szabályai, in: Juhász Ágnes (ed.), Az új Ptk. öröklési jogi szabályai, Novotni Alapítvány, Miskolc, 2016, 58.) Hornyák analyzes inheritance of land in comparisation: Zsófia Hornyák, Grunderwerb in Ungarn und im österreichischen Land Vorarlberg, JAEL, 2014/17, 68.; and Zsófia Hornyák, Die Voraussetzungen und die Beschränkungen des landwirtschaftlichen Grunderwerbes in rechtsvergleichender Analyse, CEDR Journal of Rural Law, 2015/1, 96. 
conditions affecting agricultural land, two other implementing acts will regulate this area, namely the act on agricultural operations and agricultural production. The rules concerning the organization of integrated agricultural production and on family farms (act on agricultural production) and other agricultural factories (act on agricultural factories) have not adopted yet. These future acts may include further specific provisions on the conditions of land ownership and land use. The area of agricultural affairs will be completely regulated with the adoption of these acts. Complementing these acts and enforcing the land transaction act the Parliament adopted the Act CCXII of 2013 (act on land) on certain provisions and transitional legislation correlating to the Act CXXII of 2013 on Transactions in Agricultural and Forestry Land in the beginning of December 2013. Furthermore, it should be taken account of the fact that the different provisions of forest Act and the Act on National Land Fund shall be also applied with respect to their scope. The new complex system of land regulation is based on -a different level of regulation- further implementing regulations. In addition to specific regulation, the provisions of Civil Code and the Act on the General Rules of Administrative Proceedings and Services also shall be applied. Therefore, a multi-level and complex regulation system of acquisition of arable land was established. In this study we would like to introduce the regulatory direction of agricultural land ownership without an explanation of each details. ${ }^{8}$

\section{ACQUISITION OF AGRICULTURAL LAND}

The ownership of land may be optained by specific people covered by the Act, way of the means and procedure and subject to the size limitations. In this study we will analyze the substantive rules of acquisition ignoring procedural rules and focus on who (personal limit), what (territorial limit) and how (right of disposition) can acquire. Special rules of transaction in land (prohibitive and restrictive provisions) shall not be applied to the acquisition by way of intestate succession, expropriation or through auction for the purpose of indemnification (exceptions to the general rule).

${ }^{8}$ Detailed information of new land acquisition regulation found: János Ede Szilágyi, Das landwirtschaftliche Grundstückverkehrsgesetz als erster Teil der neuen ungarischen Ordnung betreffend landwirtschaftlichen Grundstücken, Agrar- und Umweltrecht, 2015/2, 44-47. Csilla Csák - Bianka Enikő Kocsis - Anikó Raisz, Vectors and indicators of agricultural policy and law from the point of view of the agricultural land structure, JAEL, 2015/19, 32-43.; Nóra Jakab - János Ede Szilágyi, New tendencies in connection with the legal status of cohabitees and their children in the agricultural enterprise in Hungary, JAEL, 2013/15, 52-57.; István Olajos - Szabolcs Szilágyi, The most important changes in the field of agricultural law in Hungary between 2011 and 2013, JAEL, 2013/15, 101-102.; Klaudia Holló - Zsófia Hornyák - Zoltán Nagy, Die Entwicklung des Agrarrechts in Ungarn zwischen 2013 und 2015, JAEL, 2015/19, 56-64. 


\subsection{Personal limit}

Different categories of people entitled to the acquisition of land can be differentiated. As a general rule, the ownership of land may be required by domestic natural persons and EU nationals. The State (a), church (b), mortgage loan company (c) and municipal government (d) may require ownership of legal persons under special objectives and conditions without restricting the size of the land. Expect for these, legal persons may not acquire the ownership of land, furthermore, foreign natural persons (non EU nationals), other states and their provinces, municipalities and their bodies are excluded from acquisition. Current legislation is similar to the former regulation of arable land as it excludes the acquisition of legal persons and foreign natural persons.

\subsection{Territorial limit}

Analyzing the acquisition of land by natural persons it shall be stated that the Hungarian regulation distinguishes two personal groups and according to it establishes the territorial limit. The category of farmers and non farmers create two separate groups.

The new Act introduced the concept of farmer. Farmer shall mean any domestic natural person or EU national registered in Hungary, who has a degree in agricultural or forestry activities as provided for in decree, or, in the absence thereof, who has been verifiably engaged in the pursuit of agricultural and/or forestry activities, and other secondary activities in his/her own name and at his/ her own risk in Hungary continuously for at least three years, and has verifiably produced revenue by such activities. Or revenue did not materialize because the completed agricultural or forestry investment project has not yet turned productive, or verifiably holds membership for at least three years in an agricultural producer organization in which he/she has at least a 25 per cent ownership share, and who personally participates in agricultural and forestry operations, or in agricultural and forestry operations and the related secondary activities. It means that agricultural activity is the condition of the farmer's concept.

As for the rule of land acquisition limit the size of land that may be acquired by a farmer may not exceed 300 hectares (the land acquisition limit may be exceeded in certain cases). Non farmers (other than farmers) may acquire the ownership of maximum 1 hectare (earlier they could acquire 300 hectares).

\subsection{Restriction of the right of disposition}

Two legal institutions shall be mentioned in connection with the restriction of the right of disposition: one of which is the institution of preemption rights introduced by the former Act and the other is the approval by the competent authority as a new institution. 


\subsubsection{Preemption rights}

Preemption rights is not a new institution in relation to the transition of agricultural land, the former Act LV of 1994 on Arable Land also regulated the substantive rules of transition and the implementation decree of the Act regulated the procedural rules. However, the new system has other regulatory principles in relation to the group of entitled people and the rank of them and in relation to the exercise of procedural system. Preemtion rights arises in the sale of land. However, there are certain cases when the right of preemption shall not apply to any sales transaction e.g. between close relatives, joint owners of a land, concerning to subsidy, municipal purposes, etc.

Without the rank of holders of preemtion rights it can be stated that Hungarian State is still in the first place. The farmer using the land (who has been using the land of the transaction for 3 years) has a preferred place in the rank. The regulation of preemption rights -summarizing the advantages and disadvantages of the right- can be characterized as follows:

- determination of the rank is very complicated, chiselled, which raises interpretation problems during the application in many cases. It is quite complicated for certain land registered as e. g. forest, vineyard when further special legal provisions are also applicable

- the number of people entitled for preemtion rights is wide that weakens the position of the customer

- the relationship between pre-emption order and landholding policy exists and justified. On the basis of preemption rights system the purpose of the legislator remains the prevention of fragmented estate, the establishment of healthy structure of land holdings, the promotion of land acquisition by people who can and who are capable to cultivate the land

- the procedure of pre-emption rights exercise slows and increases the process of the acquisition and transaction of land.

\subsubsection{Approval by the competent authority}

The new regulation introduced serious administrative burden and strong state control of land. One of its manifestations is that the approval of administrative agricultural authority is required for the acquisition of land as a general rule. Land transaction can be classified into three groups from the aspect of authority approval: (1) acquisition of the land by sales contract (2) acquisition by other way (e.g. adverse possession, acquisition by the way of testamentary disposition, acquisition through auction or tendering as part of an enforcement or liquidation procedure, or local government debt consolidation procedure), (3) transfer of ownership eights for which the approval of the competent authority is not required. 
As a general rule, the approval of the competent authority is required for the transfer of ownership (in the case of land use agreement) but the approval of agricultural administration autority is not required:

- for State, church, mortgage loan company, municipal government acquisitions

- for the alienation of land owned by the State or by any municipal government

- for the transfer of ownership of land by way of a gift

- for transactions of ownership between close relatives

- for transfers of ownership between joint owners, if it results in the termination of joint ownership

- for sales transactions by way of conveyance to another farmer in conformity with the relevant legislation, as a precondition for subsidy

- for acquisitions within the framework of authorization of parcel reconfiguration. The agricultural administration authority (authority) checks the eligibility of the land buyer, the compliance of ownership acquisition limit, circumstances for validating the contract of sale (possibility of so called pocket contracts) and conditions of acquisition. ${ }^{9}$ The authority also checks the conditions and restrictions of acquisition and the observation of prohibitions after the acquisition of the land and during this time period the authority experiences that the owner or the land user breaks the rule will be advised concerning the infringement and instruct them in writing to restore compliance within the time limit prescribed. If the owner or the land user fails to comply with the notice, the agricultural administration body shall impose a default penalty. The forint amount of the default penalty shall be calculated based on the gold crown value of the land at the time of acquisition, multiplied by twenty thousand. Exemption from payment of the default penalty shall not be granted. The default penalty may be imposed repeatedly if the infringement prevails and if the obligor fails to eliminate the infringement in six months time, the agricultural administration body shall move to provide for the regulatory use of the land. It has no effect on ownership rights and in this situation the use of the land will be transferred.

\section{CLOSING THOUGHTS}

The special natural and financial characters of land ownership are on one hand the finite good being of the land (land as a natural object is limited and can not be propagated and can not be replaced), its indispensability, its renewable

\footnotetext{
${ }^{9}$ All of it see István Olajos: Az Alkotmánybíróság döntése a helyi földbizottságok szerepéről, döntéseiről, és az állásfoglalásuk indokainak megalapozottságáról, Jogesetek Magyarázata, 2015/3, 17-32.; és István Olajos, Die Entscheidung des Verfassungsgerichts über die Rolle, die Entscheidungen und die Begründetheit der Gründen der Stellungnahmen der örtlichen Grundverkehrskommissionen, Agrar- und Umweltrecht, 2017/8.,284-291.
} 
feature, its special risk-sensitivity and its low profit, which create the special social feature of land ownership. ${ }^{10}$ These circumstances justify the enforcement of public interest against ownership rights. The Constitutional Court has already stated that the legal treatment of land ownership due to its specificity is different from other property subjects that are justified in some respects. ${ }^{11}$ On the other hand in the case of land ownership issues it can not be ignored that one of the essential factors of state sovereignty is the land acquisition of the state. These two aspects also support the importance of this area and the reasonableness of strict regulation. ${ }^{12}$

The Acts regulate provisions taken to eliminate speculative contracts made for circumventing the rules of acquisition. The instruments of these provisions are the preemption rights, the introduction of authority approval and the new crimes of Criminal Code introduced during its amendment which proposed criminal penalties for lawyers, notaries, etc. involved in these transaction in the case of illegal land acquisition

It is well known that the new land transaction act had and has a lot of national and union criticism until today. It is very important like in the case of every law how the problems will be dealt by the domestic case law. ${ }^{13}$ Legislation is not always clear and can not regulate all situations occurring in life that would require further legislative solutions. By way of introduction the regulation of agricultural land is not complex, further legal requirements will supplement the current regulation which may change some regulatory subjects in certain situations.

10 35/1994. (VI. 24.) Constitutional Court Decision

11 16)1991. (IV. 20.) Constitutional Court Decision, Constitutional Court Decision 1991.62., 64/1993. (XII. 22.) CCD, CCD 1993. 381.

12 Ede János Szilágyi pointed out the meaning of land-grabbing within the EU. Published: János Ede Szilágyi, Conclusions, JAEL, 2015/19, 91-92., János Ede Szilágyi, The Accession Treaties of the New Member States and the national legislations, particularly the Hungarian law, concerning the ownership of agricultural land, JAEL, 2010/9, 48-51., 55., 59-60.

${ }^{13}$ Tamás Andréka - István Olajos, A földforgalmi jogalkotás és jogalkalmazás végrehajtása kapcsán felmerült jogi problémák elemzése, Magyar Jog 2017/7-8.,410-424. 
Др Чила Чак, доиенӣ

Универзииетей у Мищколиу

Правни факулиетеи

dattila@yunord.net

\section{Уређење права својине на пољопривредном земљишту у Мађарској након укидања земљишног мораторијума}

Сажейак: Обрадиво земљищйе је једно од највреднијих ириродних ресурса земље, које тиреба ииретиирайи као заједничко начионално наслеђе. Држава, али и сваки йојединац одг̄оворни су за њег̄ову зашииийу и очување за будуће геенерачије, шимио налаже Део (1) члана П) Основног̄ закона Мађарске. Нови Закон о иромейу земљищйа (Закон СХХІІ из 2013. гоодине о йро-

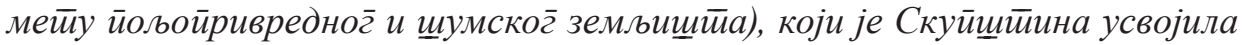
21. јуна 2013. гоодине, наситоји да обезбеди осивварење ових ииљева, уређујући сущитинске и кључне елемение стиицања иррава својине на земљищйу након укидања моратиоријума у йогледу стиицања иррава својине на земљищйу. Закон ирредвиђа матиеријалноиравна и ироцеснойравна рещења која би ииребало да осигуурају инитересе земље. У оквиру истираживања, биће, с једне стиране, ирредстиваљена и анализирана очекивања и иринцийи Евройске уније,

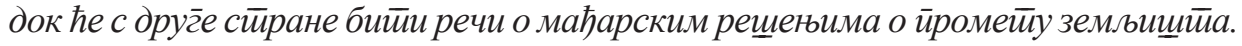

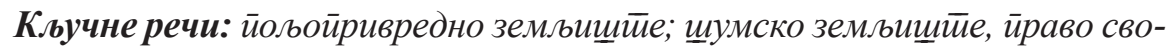
јине, ирава сииранаиа.

Датум пријема рада: 09.10.2017. 